\title{
Front Matter: Volume 9738
}

, "Front Matter: Volume 9738," Proc. SPIE 9738, Laser 3D Manufacturing III, 973801 (15 March 2016); doi: 10.1117/12.2239308

SPIE. Event: SPIE LASE, 2016, San Francisco, California, United States 


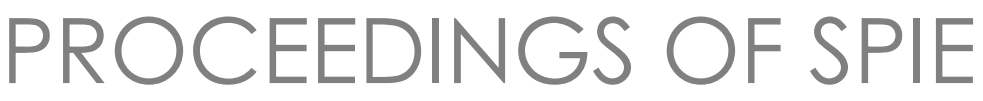

\section{Laser 3D Manufacturing III}

Bo Gu

Henry Helvajian

Alberto Piqué

Editors

15-18 February 2016

San Francisco, California, United States

Sponsored by

SPIE

Cosponsored by

PolarOnyx, Inc. (United States)

Nanoscribe GmbH (Germany)

Published by

SPIE 
The papers in this volume were part of the technical conference cited on the cover and title page. Papers were selected and subject to review by the editors and conference program committee. Some conference presentations may not be available for publication. Additional papers and presentation recordings may be available online in the SPIE Digital Library at SPIEDigitallibrary.org.

The papers reflect the work and thoughts of the authors and are published herein as submitted. The publisher is not responsible for the validity of the information or for any outcomes resulting from reliance thereon.

Please use the following format to cite material from these proceedings:

Author(s), "Title of Paper," in Laser 3D Manufacturing III, edited by Bo Gu, Henry Helvajian, Alberto Piqué, Proceedings of SPIE Vol. 9738 (SPIE, Bellingham, WA, 2016) Six-digit Article CID Number.

ISSN: 0277-786X

ISSN: 1996-756X (electronic)

ISBN: 9781628419733

Published by

SPIE

P.O. Box 10, Bellingham, Washington 98227-0010 USA

Telephone +1 3606763290 (Pacific Time) · Fax +1 3606471445

SPIE.org

Copyright (C) 2016, Society of Photo-Optical Instrumentation Engineers.

Copying of material in this book for internal or personal use, or for the internal or personal use of specific clients, beyond the fair use provisions granted by the U.S. Copyright Law is authorized by SPIE subject to payment of copying fees. The Transactional Reporting Service base fee for this volume is $\$ 18.00$ per article (or portion thereof), which should be paid directly to the Copyright Clearance Center (CCC), 222 Rosewood Drive, Danvers, MA 01923. Payment may also be made electronically through CCC Online at copyright.com. Other copying for republication, resale, advertising or promotion, or any form of systematic or multiple reproduction of any material in this book is prohibited except with permission in writing from the publisher. The CCC fee code is 0277-786X/16/\$18.00.

Printed in the United States of America.

Publication of record for individual papers is online in the SPIE Digital Library.

\section{SPIE. DIGITAL}

Paper Numbering: Proceedings of SPIE follow an e-First publication model. A unique citation identifier (CID) number is assigned to each article at the time of publication. Utilization of CIDs allows articles to be fully citable as soon as they are published online, and connects the same identifier to all online and print versions of the publication. SPIE uses a six-digit CID article numbering system structured as follows:

- The first four digits correspond to the SPIE volume number.

- The last two digits indicate publication order within the volume using a Base 36 numbering system employing both numerals and letters. These two-number sets start with 00, 01, 02, 03, 04, $05,06,07,08,09,0 A, 0 B \ldots$ OZ, followed by 10-1Z, 20-2Z, etc. The CID Number appears on each page of the manuscript. 


\title{
Contents
}

\author{
vii Authors \\ ix Conference Committee \\ xi Industry Panel \\ xiii Introduction
}

LASER 3D MICRO/NANO STRUCTURING: JOINT SESSION WITH CONFERENCES 9735 AND 9738

973803 Improvement in contact resistance of $4 \mathrm{H}-\mathrm{SiC}$ by excimer laser doping using silicon nitride films $[9738-1]$

973804 A cantilever based optical fiber acoustic sensor fabricated by femtosecond laser micromachining [9738-2]

LASER DIRECT WRITING: JOINT SESSION WITH CONFERENCES 9735 AND 9738

973805 Laser-assisted inkjet printing of highly viscous fluids with sub-nozzle resolution [9738-3]

973806 Laser printing and femtosecond laser structuring of electrode materials for the manufacturing of 3D lithium-ion micro-batteries [9738-4]

3D LASER STRUCTURING DEVICES AND LITHOGRAPHY III: JOINT SESSION WITH CONFERENCES 9738 AND 9759

973808 Precise 3D printing of micro/nanostructures using highly conductive carbon nanotubethiol-acrylate composites [9738-6]

973809 Potential for GPC-based laser direct writing [9738-7]

3D LASER STRUCTURING DEVICES AND LITHOGRAPHY IV: JOINT SESSION WITH CONFERENCES 9738 AND 9759

9738 OA 3D light robotics (Invited Paper) [9738-8]

9738 OC Advanced two-photon photolithography for patterning of transparent, electrically conductive ionic liquid-polymer nanostructures (3D Printing Best Paper Award) [9738-10] 
LASER INDUCED FORWARD TRANSFER (LIFT)

9738 Ol Laser printing of 3D metallic interconnects [9738-12]

MATERIALS, PROCESSES, AND POST-PRINTING PROCESSES FOR ADDITIVE MANUFACTURING

9738 OK 3D manufacturing of micro and nano-architected materials (Invited Paper) [9738-14]

$973800 \quad$ Review on laser powder injection additive manufacturing of novel alloys and composites (Invited Paper) [9738-18]

MODELING, DESIGN, PROCESS MONITORING, AND CONTROLS FOR ADDITIVE MANUFACTURING

$97380 Q \quad$ Towards in-situ process monitoring during additive manufacturing using optical coherence tomography [9738-20]

9738 OR Sensing for directed energy deposition and powder bed fusion additive manufacturing at Penn State University (Invited Paper) [9738-21]

9738 OS Optical design and initial results from NIST's AMMT/TEMPS facility [9738-22]

9738 OT Towards photo-induced swimming: actuation of liquid crystalline elastomer in water (Invited Paper) [9738-23]

SLM, DMLS, SLS, SLM WITH ULTRAFAST LASERS

9738 OU Femtosecond fiber laser additive manufacturing of tungsten (Invited Paper) [9738-24]

9738 OW Laser post-processing of Inconel 625 made by selective laser melting [9738-26]

9738 OX Fabrication and heat treatment of high strength $\mathrm{Al}-\mathrm{Cu}-\mathrm{Mg}$ alloy processed using selective laser melting [9738-27]

APPLICATIONS, SYSTEMS, PROCESS DEVELOPMENTS FOR ADDITIVE MANUFACTURING I

9738 OY Additive manufacturing of glass for optical applications (3D Printing Best Paper Award) [9738-28]

$97380 Z$ Reducing residual stresses and deformations in selective laser melting through multi-level multi-scale optimization of cellular scanning strategy [9738-29]

973810 Application of laser ultrasonic non-destructive evaluation technique to additive manufacturing [9738-30]

973811 Repurposing mainstream CNC machine tools for laser-based additive manufacturing (Invited Paper) [9738-31] 
APPLICATIONS, SYSTEMS, PROCESS DEVELOPMENTS FOR ADDITIVE MANUFACTURING II

$973813 \mathrm{X}$-band printed phased array antennas using high-performance CNT/ion gel/Ag transistors (Invited Paper) [9738-34]

973816 The application of digital medical 3D printing technology on tumor operation (Invited Paper) [9738-37]

POSTER SESSION

973817 Experiments for practical education in process parameter optimization for selective laser sintering to increase workpiece quality [9738-38]

9738 1B Improving accuracy of overhanging structures for selective laser melting through reliability characterization of single track formation on thick powder beds [9738-44]

9738 1C Experimental study on Ti alloy plate fabrication by vacuum selective laser melting [9738-45] 
Proc. of SPIE Vol. $9738973801-6$

Downloaded From: https://www.spiedigitallibrary.org/conference-proceedings-of-spie on 25 Apr 2023 Terms of Use: https://www.spiedigitallibrary.org/terms-of-use 


\section{Authors}

Numbers in the index correspond to the last two digits of the six-digit citation identifier (CID) article numbering system used in Proceedings of SPIE. The first four digits reflect the volume number. Base 36 numbering is employed for the last two digits and indicates the order of articles within the volume. Numbers start with 00, 01, 02, 03, 04, 05, 06, 07, 08, 09, OA, OB...0Z, followed by 10-12, 20-2Z, etc.

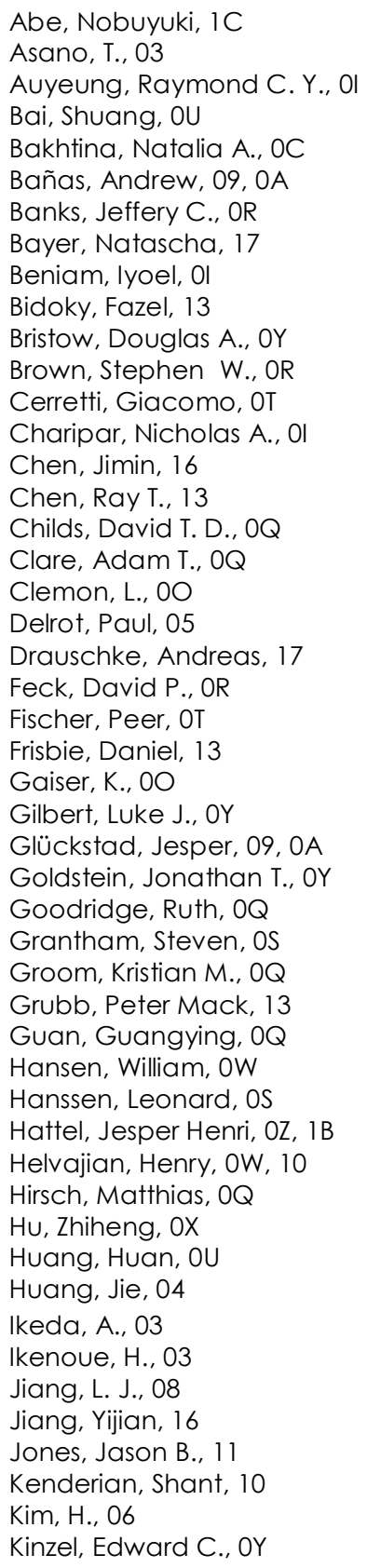

Kojima, R., 03

Korvink, Jan G., OC Landers, Robert G., OY Lane, Brandon, OS Lavernia, E. J., 00

Li, Wentao, 13

Li, Yangsheng, 16

Liv, Jian, OU

Liu, Jie, 04

Liu, Y., 08

LU, W. Y., 00

LU, Y. F., 08

LU, Zeng Hai, $O Q$

Luo, Junjie, OY

MacKinnon, Neil, OC

Mahajan, Ankit, 13

Manzo, Anthony J., 10

Mark, Andrew G., OT

Martella, Daniele, OT Masuno, Shinichiro, 1C Matcher, Stephen J., OQ Mathews, Scott A., Ol Mekhontsev, Sergey, OS Melde, Kai, OT

Modestino, Miguel A., 05 Mohanty, Sankhya, 0Z, IB Morgan, Jacob P., Jr., OR Morgan, Jr., John P., OR Moser, Christophe, 05 Nakamura, D., 03 Nassar, Abdalla R., OR Natale, Donald J., OR Neira, Jorge, OS

Nie, Xiaojia, OX

Okada, T., 03

Palagi, Stefano, OT

Palima, Darwin, OA

Parmeggiani, Camilla, OT

Pfleging, W., 06

Piqué, Alberto, 06, 01

Psaltis, Demetri, 05

Qi, Ting, OX

Qiv, Tian, OT

Reutterer, Bernd, 17

Reutzel, Edward W., OR

Sato, Yuji, 1C

Schoenung, J. M., 00

Seifert, H. J., 06

Smyrek, P., 06 
Steffeney, Lee, OW

Subbaraman, Harish, 13

Suwa, M., 03

Traxler, Lukas, 17

Tsukamoto, Masahiro, 1C

Tutwiler, Rick L., OR

Urbas, Augustine M., OY

Valdevit, Lorenzo, OK

Villangca, Mark, OA

Vlasea, Mihaela, OS

Wiersma, Diederik S., OT

Witkin, David, OW

Xiao, Hai, 04

Xiong, W., 08

Yamashita, Yorihiro, 1C

Yang, Lih-Mei, OU

Yang, N., 00

Yang, Pei, OU

Yee, J., 00

Yuan, Lei, 04

Zeng, Hao, OT

Zeng, Xiaoyan, OX

Zhai, Meiyu, OU

Zhang, $\mathrm{Hu}, \mathrm{OX}$

Zheng, B., 00

Zheng, Y., 06

Zhou, Y. S., 08

Zhou, Y., 00

Zhu, Haihong, OX 


\section{Conference Committee}

Symposium Chairs

Guido Hennig, Daetwyler Graphics AG (Switzerland)

Yongfeng Lu, University of Nebraska-Lincoln (United States)

Symposium Co-chairs

Reinhart Poprawe, Fraunhofer-Institut für Lasertechnik (Germany)

Koji Sugioka, RIKEN (Japan)

Program Track Chair

Bo Gu, Bos Photonics (United States)

Conference Chairs

Bo Gu, Bos Photonics (United States)

Henry Helvajian, The Aerospace Corporation (United States)

Alberto Piqué, U.S. Naval Research Laboratory (United States)

Conference Program Committee

John T. Fourkas, University of Maryland, College Park (United States)

Youping Gao, Aerojet Rocketdyne (United States)

Craig Goldberg, Newport Corporation (United States)

Weidong Huang, Northwestern Polytechnical University (China)

Jian Liu, PolarOnyx, Inc. (United States)

Michael Thiel, Nanoscribe GmbH (Germany)

Paul S. Unwin, Stanmore Implants (United Kingdom)

Augustine M. Urbas, Air Force Research Laboratory (United States)

Martin Wegener, Karlsruher Institut für Technologie (Germany)

\section{Session Chairs}

1 Laser 3D Micro/Nano Structuring: Joint Session with Conferences 9735 and 9738

Henry Helvajian, The Aerospace Corporation (United States)

2 Laser Direct Writing: Joint Session with Conferences 9735 and 9738

Costas P. Grigoropoulos, University of California, Berkeley

(United States) 
3 3D Laser Structuring Devices and Lithography I: Joint Session with Conferences 9738 and 9759

Stephen M. Kuebler, University of Central Florida (United States)

4 3D Laser Structuring Devices and Lithography II: Joint Session with Conferences 9738 and 9759

Georg von Freymann, Technische Universität Kaiserslautern (Germany)

5 3D Laser Structuring Devices and Lithography III: Joint Session with Conferences 9738 and 9759

Winston V. Schoenfeld, CREOL, The College of Optics and Photonics, University of Central Florida (United States)

6 3D Laser Structuring Devices and Lithography IV: Joint Session with Conferences 9738 and 9759

Michael Thiel, Nanoscribe GmbH (Germany)

Industry Panel on 3D Printing: Outlook and Opportunities

Bo Gu, Bos Photonics (United States)

7 Laser Induced Forward Transfer (LIFT)

Craig Goldberg, Newport Corporation (United States)

8 Materials, Processes, and Post-Printing Processes for Additive Manufacturing

Henry Helvajian, The Aerospace Corporation (United States)

9 Modeling, Design, Process Monitoring, and Controls for Additive Manufacturing

Alberto Piqué, U.S. Naval Research Laboratory (United States)

10 SLM, DMLS, SLS, SLM with Ultrafast Lasers

Alberto Piqué, U.S. Naval Research Laboratory (United States)

11 Applications, Systems, Process Developments for Additive Manufacturing I

Jian Liu, PolarOnyx, Inc. (United States)

12 Applications, Systems, Process Developments for Additive Manufacturing II

Bo Gu, Bos Photonics (United States) 


\section{Industry Panel on 3D Printing: Outlook and Opportunities}

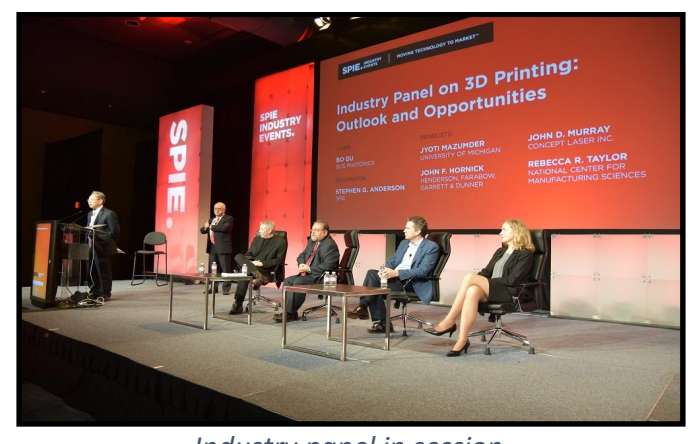

Industry panel in session

Kick off the 3D conference with this informative business session.

Market analysts valued the global 3D printing market at \$2.3B in 2013 and are projecting global revenues of $\$ 8.6 \mathrm{~B}$ by 2020 - an impressive compound annual growth rate of more than $20 \%$ over seven years! At the same time, Siemens estimates that 3D printing will become $50 \%$ less expensive and $400 \%$ faster over the next five years.

However, 3D printing can only reach its economic potential and fulfill its promise of revolutionizing manufacturing across multiple industries if a number of significant real-world structural challenges are addressed. Hurdles to widespread implementation of 3D printing include implementation of a proper regulatory framework, provisions to protect intellectual property, and establishment of appropriate standards and certification, to name a few.

Many joined us for a panel discussion about these hurdles and how they might be overcome. Expert perspectives on 3D printing technology, cyber security, intellectual property, and other key elements were addressed, as well as the widespread adoption of 3D printing. Industry leaders shared their views on the outlook for 3D printing and what they think needs to happen for digital manufacturing to go mainstream and fulfill its promise to create a broad range of new opportunities.

SPEAKERS/PANELISTS:

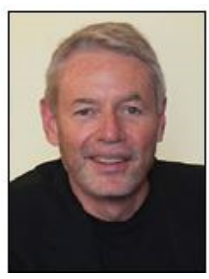

3D Printing Will Rock the World John F. Hornick

Partner, Finnegan, Henderson, Farabow, Garrett \& Dunner, L.L.P. (United States)

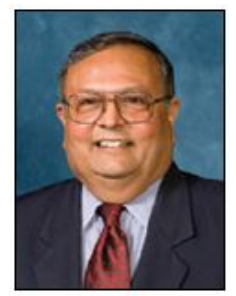

Smart Additive Manufacturing Systems (S-AMS) Jyoti Mazumder

Univ. of Michigan (United States) 


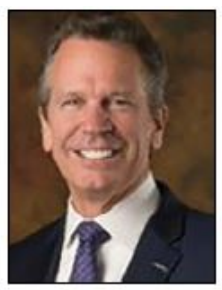

3D Printing and the Future of Manufacturing John D. Murray

Concept Laser, Inc. (United States)

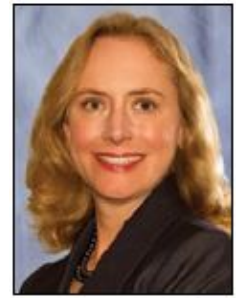

Cyber Security Concerns in 3D Printing Rebecca R. Taylor

Senior Vice President for the National Center for Manufacturing Sciences (NCMS)

(United States)

Panel Discussion with Q\&A followed

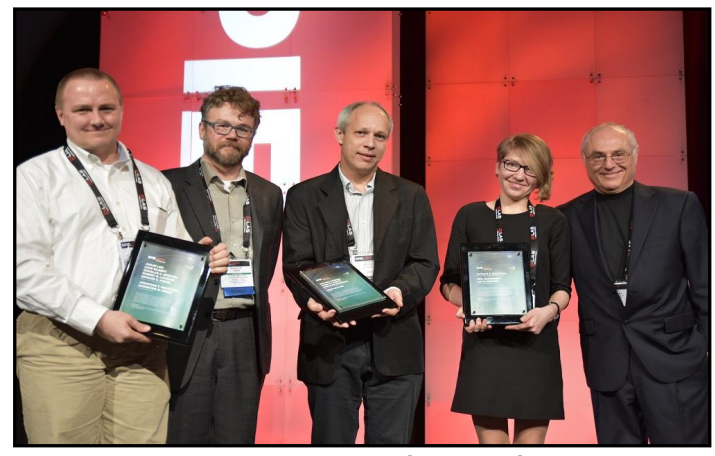

Award recipients with one of the conference chairs

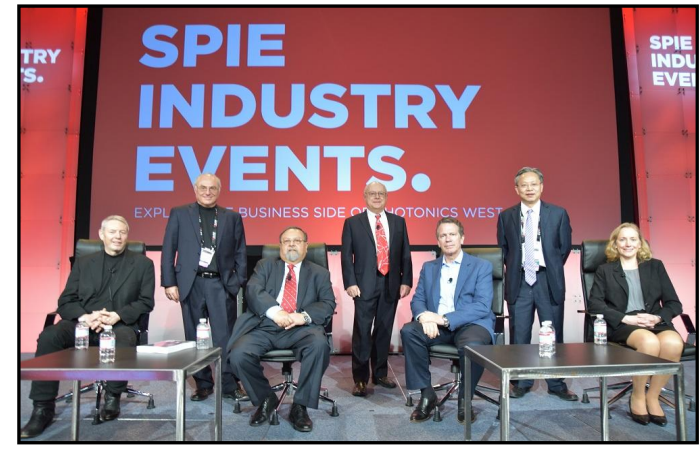

This year's panelists with the conference chairs 


\section{Introduction}

Potentially a disruptive game changer, Laser Additive Manufacturing (LAM), or 3D Laser Printing as it is commonly known, has captured the popular imagination. While LAM is still a relatively new technology and definitely needs further development, it has already been disrupting the manufacturing value chain and allowing a path to mass producing customized products. In some applications, it has already reached a tipping point of maturity. However, to fully reach LAM economic potential and to fulfill its promise to create wealth it takes much more than just pure technological development. There are enormous challenges remained to be tackled: regulatory framework, intellectual properties, product liabilities, standardization and certification, cyber security to name just a few.

The Laser 3D Manufacturing Conference at Photonics West was very unique. It provided a forum for professionals from multiple disciplines to share and discuss the latest advances in the field of laser-based digital manufacturing and the development and implementation of next generation laser-based 3D manufacturing processes. We believe this type of cross talk and communication amongst conference speakers and attendees from all fields related to LAM (which include material science, laser processing physics/chemistry, mechanical engineering, software and designing tools, modeling, characterization and metrology) is not only necessary for maturing the field but also very much needed to spark new ideas.

To further facilitate this goal of exploring and pushing this new technology to its full potential, realizing the economic opportunity across multiple industries for service providers, systems manufacturers and photonics companies, and providing a realistic assessment of how digital manufacturing technology, applications, and markets will evolve in the near future; we assembled an industry panel on 3D Printing Manufacturing for the first time within the conference. Leaders from various areas gave their perspective and outlooks on this very exciting evolving field. Experts advised us to certify as we build products due to the prohibitive high cost of design change. They also warned us that business models will evolve and that the way of making products will be fundamentally changed. These changes will present challenges to current intellectual property laws. They will also bring concerns over the cyber security. Overall, this inaugural industry panel was well attended and received. It was a success. 
Finally, we would like to thank all conference speakers, panelists, and attendees for their contribution to the conference. We hope that more people will come and share their work at this unique platform next year. After all, this is what this conference is all about - it is for you.

Bo Gu

Henry Helvajian

Alberto Piqué 